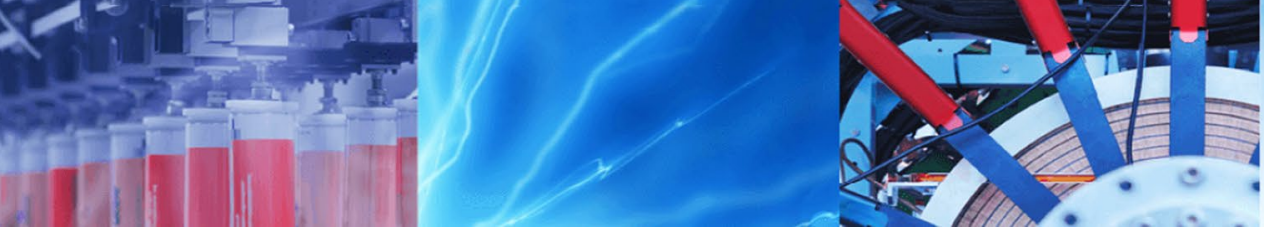

Research Article

\title{
Heavy metals concentrations in selected soil samples of Al-Diwaniyah governorate, Southern Iraq
}

\author{
Anees A. Al-Hamzawi ${ }^{1}$. $\cdot$ Majied G. Al-Gharabi ${ }^{1}$
}

(c) Springer Nature Switzerland AG 2019

\begin{abstract}
Heavy metals' origin, accumulation, and distribution in soil samples have been the focus of much attention by many researchers to monitor soil pollution. The objective of this study is to determine the levels of the heavy metals such as lead $(\mathrm{Pb})$, cadmium $(\mathrm{Cd})$, copper $(\mathrm{Cu})$, and zinc $(\mathrm{Zn})$ in the soil samples collected from different areas residential, industrial and agricultural of Al-Diwaniyah governorate southern Iraq using the effective technique of atomic absorption spectroscopy $\mathrm{AAS}$, so that the degree of pollution could be ascertained. The results show that the mean values of $\mathrm{Pb}, \mathrm{Cd}, \mathrm{Cu}$ and $\mathrm{Zn}$ concentrations in soil samples are 31.75, 1.804, 18.51 and $29.82 \mathrm{mg} / \mathrm{l}$, respectively. The results show that the heavy metals concentrations were found to be higher in industrial regions than the other locations. Mean values of $\mathrm{Pb}$ and $\mathrm{Cd}$ in soils studied were generally higher than the acceptable limits, suggesting some degrees of pollution with heavy metals.
\end{abstract}

Keywords Heavy metals · Soil samples · Pollution · AAS · AI-Diwaniyah

\section{Introduction}

Human activities in areas with a high proportion of industrial and urban development have contributed in environmental contamination. Soil pollution caused by toxic metals has harmful effects on the human health and environmental balance. Heavy metals such as $\mathrm{Pb}, \mathrm{Cu}$, $\mathrm{Zn}$ and $\mathrm{Cd}$ in urban soils are clear indicators of environmental contamination [1-5]. The main reason for heavy metals contamination in soil samples of urban areas is the human activities which include industrial waste and vehicle emissions among others. Emission of toxic metals as a result of man-made activities exceeds emission from natural sources. Due to the widespread use of heavy metals in a wide range of manufacturing processes so that the exposure to these elements is common in industry $[6,7]$. According to the environmental studies, the main source of the contamination by toxic metals in environment is anthropogenic source. The anthropogenic sources of toxic metals in urban soils are traffic emission which includes vehicle exhaust and tire wear particles. Also, industrial emission includes power plants, auto repair shop, metallurgical industry and chemical plant. However, in agricultural soils the anthropogenic sources of toxic metals involve using chemical fertilizers, pesticides and vehicle exhausts and so on [8-11]. Heavy metals can enter into the human body through ingesting food and water which are contamined by toxic elements or by inhaling dust particles containing toxic elements. When the toxic metals enter the human body will transfer through the blood into the different organs, causing several healthy problems for the exposed individuals where these elements are considered as a possible human carcinogen $[12,13]$. Availability and distribution of toxic metals in soil samples are important when assessing the environmental quality of an area. The environment in Iraq has been suffered from the increasing levels of toxic elements in a way affecting the ecological balance and Iraqis' health as a result of the human activity, especially in the southern part of the country [14-17]. The chemical analysis of soil samples is the preferred method

Anees A. Al-Hamzawi, aneesphys@gmail.com; anees.hassan@qu.edu.iq | ${ }^{1}$ Department of Physics, College of Education, University of AlQadisiyah, Diwaniyah, Iraq.

SN Applied Sciences (2019) 1:854 | https://doi.org/10.1007/s42452-019-0892-7

Received: 11 March 2019 / Accepted: 6 July 2019 / Published online: 15 July 2019 
for monitoring the external exposure of toxicological contaminants. There is not adequate information about heavy metal levels in soil samples of Al-Diwaniyah governorate therefor, this study is aimed to determine the concentrations of $\mathrm{Pb}, \mathrm{Cd}, \mathrm{Cu}$ and $\mathrm{Zn}$ in soil samples collected from various areas residential, industrial and agricultural of Al-Diwaniyah governorate southern Iraq by using atomic absorption spectroscopy. Results of the investigation are compared with the allowable levels worldwide.

\section{Material and method}

\subsection{Sample collection}

The present estimation was based on the study of 20 soil samples collected from differentiated areas in nature residential, industrial and agricultural in Al-Diwaniyah governorate southern Iraq, as shown in Table 1. Al-Diwaniyah governorate has a total area of $8153 \mathrm{~km}^{2}$ and the population was estimated to be $1,320,000$ people [18]. It is located between $31^{\circ} .73^{\prime} \mathrm{N}, 44^{\circ} .69^{\prime} \mathrm{E}$. About $10 \mathrm{~g}$ of soil samples, which are sufficient for getting the required amount for atomic absorption spectroscopy. The samples were stored in plastic vials with the code of the sample to the time of analysis.

\subsection{Experimental method}

The experimental technique for the estimation of heavy metals contents in soil samples is the same as reported elsewhere [19-21]. Soil samples were dried using an electric oven at $100^{\circ} \mathrm{C}$ for $2 \mathrm{~h}$. The samples were grinded using a hand mill, and then the samples were sieved using a fine mesh of $75 \mu \mathrm{m}$ for homogenization to prepare them for laboratory procedures. The dried soil samples, weighing $1 \mathrm{~g}$ in containers were digested by adding $150 \mathrm{ml}$ of $\mathrm{HCl}$ with $5 \mathrm{ml}$ of acid nitric $\mathrm{HNO}_{3}$. The samples were placed on a sandy bath for $60 \mathrm{~min}$. Then, the containers were cooled and added $5 \mathrm{ml}$ of $\mathrm{HCl}$ and $50 \mathrm{ml}$ of distilled water to wash the sides of the container from the dissolved sample. The mixture was heated to boiling point for $3 \mathrm{~min}$ after that the sample was filtered using a filter sheet and the sample was collected with volume of $100 \mathrm{ml}$ in a special containers. The mineralised samples were stored in a refrigerator at temperature of $4^{\circ} \mathrm{C}$ up to the time of analysis. Contents of $(\mathrm{Pb}, \mathrm{Cd}, \mathrm{Cu}$, and $\mathrm{Zn})$ in soil samples were measured using atomic absorption spectroscopy AAS (Biotech Engineering Management Ltd, UK) which enables elemental analysis at percentage to parts per million (ppm) levels for a wide range of metals. Calibration procedure was undertaken prior the use of the AAS in order to analyse the samples. Standard solutions used in calibration were prepared by

Table 1 Demographic information of the study areas in Al-Diwaniyah governorate

\begin{tabular}{|c|c|c|c|}
\hline Name of area & Sample code & Coordinates & Area classification \\
\hline Al-Forat district & S1 & $32^{\circ} .03^{\prime} \mathrm{N}, 44^{\circ} .89^{\prime} \mathrm{E}$ & Industrial_Electrical power plant \\
\hline Al-Thaqlin district & S2 & $31^{\circ} .96^{\prime} \mathrm{N}, 44^{\circ} .95^{\prime} \mathrm{E}$ & Industrial_Factory of plastic and fabric \\
\hline Al-Askari district & S3 & $31^{\circ} .99^{\prime} \mathrm{N}, 44^{\circ} .94^{\prime} \mathrm{E}$ & Residential \\
\hline Al-Wahda district & S4 & $31^{\circ} .99^{\prime} \mathrm{N}, 44^{\circ} .95^{\prime} \mathrm{E}$ & Residential—Main road and traffic jam \\
\hline Al-Jameih district & S5 & $31^{\circ} .97^{\prime} \mathrm{N}, 44^{\circ} .95^{\prime} \mathrm{E}$ & Residential \\
\hline Al-Nahda district & S6 & $31^{\circ} .98^{\prime} \mathrm{N}, 44^{\circ} .95^{\prime} \mathrm{E}$ & Residential \\
\hline Al-Sinaeiu district & S7 & $31^{\circ} .98^{\prime} \mathrm{N}, 44^{\circ} .89^{\prime} \mathrm{E}$ & Industrial_Car repair garage \\
\hline Al-jamieih district & S8 & $31^{\circ} .99^{\prime} \mathrm{N}, 44^{\circ} .87^{\prime} \mathrm{E}$ & Residential \\
\hline Al-Taamim district & S9 & $31^{\circ} .98^{\prime} \mathrm{N}, 44^{\circ} .93^{\prime} \mathrm{E}$ & Residential—Main road and traffic jam \\
\hline Al- Eidharia district & S10 & $31^{\circ} .98^{\prime} \mathrm{N}, 44^{\circ} .91^{\prime} \mathrm{E}$ & Agricultural \\
\hline Al-Dagharah city & S11 & $32^{\circ} .06^{\prime} \mathrm{N}, 44^{\circ} .77^{\prime} \mathrm{E}$ & Agricultural \\
\hline Al-Saniya city & S12 & $32^{\circ} .07^{\prime} \mathrm{N}, 44^{\circ} .77^{\prime} \mathrm{E}$ & Agricultural \\
\hline Al-Hamad village & $\mathrm{S} 13$ & $31^{\circ} .99^{\prime} \mathrm{N}, 44^{\circ} .97^{\prime} \mathrm{E}$ & Industrial_Electrical power plant \\
\hline Afak city (Al-Rasul district) & S14 & $32^{\circ} .03^{\prime} \mathrm{N}, 45^{\circ} .14^{\prime} \mathrm{E}$ & Industrial—Car repair garage \\
\hline Afak city (Or district) & $\mathrm{S} 15$ & $32^{\circ} .04^{\prime} \mathrm{N}, 45^{\circ} .18^{\prime} \mathrm{E}$ & Residential \\
\hline Afak city (Al-Shurta district) & S16 & $32^{\circ} .06^{\prime} \mathrm{N}, 45^{\circ} .24^{\prime} \mathrm{E}$ & Residential \\
\hline Sumer city & S17 & $32^{\circ} .14^{\prime} \mathrm{N}, 44^{\circ} .99^{\prime} \mathrm{E}$ & Agricultural \\
\hline Nifar city & $\mathrm{S} 18$ & $32^{\circ} .12^{\prime} \mathrm{N}, 45^{\circ} .23^{\prime} \mathrm{E}$ & Agricultural \\
\hline Al-Hamza city & S19 & $31^{\circ} .73^{\prime} \mathrm{N}, 45^{\circ} .00^{\prime} \mathrm{E}$ & Residential \\
\hline Al-Sahmiya city & S20 & $31^{\circ} .97^{\prime} \mathrm{N}, 44^{\circ} .69^{\prime} \mathrm{E}$ & Industrial_Electrical power plant \\
\hline
\end{tabular}


diluting multi-elemental standard solutions of concentration of $100 \mathrm{mg} / \mathrm{l}$.

\section{Results and discussion}

Table 2 illustrates the concentrations of heavy metals in soil samples of Al-Diwaniyah governorate. From this table, the highest value of $\mathrm{Pb}$ concentration is $41 \mathrm{mg} / \mathrm{l}$ found in soil sample of Al-Taamim district (S9) where this area is a main road and traffic jam. Therefore, the levels of $\mathrm{Pb}$ were higher, whereas the lowest value of $\mathrm{Pb}$ concentration obtained is $20 \mathrm{mg} / \mathrm{l}$ found in Al-Jameih district (S5) where this area is residential and free from human activities. Thus, the mean value of $\mathrm{Pb}$ content in soil samples of Al-Diwaniyah governorate is $31.75 \pm 2.65 \mathrm{mg} / \mathrm{l}$. The result of $\mathrm{Pb}$ content in studied soil is about threefold higher than the normal level of $\mathrm{Pb}$ in soil $10 \mathrm{mg} / \mathrm{l}$ [22]. This finding indicates that the soil samples of the study area are polluted by $\mathrm{Pb}$ metal as a result of human activities where usage this metal in a wide range of manufacturing and vehicle emissions. On other hand, the concentration of $\mathrm{Cd}$ in soil samples ranged from $0.98 \mathrm{mg} / \mathrm{l}$ found in soil of Al-jamieih district (S8) of a residential nature to $2.72 \mathrm{mg} / \mathrm{l}$ in soil sample of Al-Sinaeiu district (S7), which contains car repair garages, with the mean value of $C d$ in soil samples of the study area is $1.804 \pm 0.43 \mathrm{mg} / \mathrm{l}$. The mean value of $\mathrm{Cd}$ concentrations in soil samples exceeds the safety level of $\mathrm{Cd} 0.12 \mathrm{mg} / \mathrm{l}$ as reported elsewhere [22]. These results indicate that the soil samples of the study are polluted by $\mathrm{Cd}$ metal due to the industrial activities and absence of the environmental monitoring. The maximum value of Cu concentration in soil samples is $24.12 \mathrm{mg} / \mathrm{l}$ found in Al-Sinaeiu district, while the minimum value of $\mathrm{Cu}$ level is $13.3 \mathrm{mg} / \mathrm{l}$ found in Al-Askari district of a residential nature (S3). The average value of $\mathrm{Cu}$ content in the studied soil samples is $18.51 \pm 2.77 \mathrm{mg} / \mathrm{l}$, where this value is within the normal level of $\mathrm{Cu}$ in soil samples $18.7 \mathrm{mg} / \mathrm{l}$ [22]. The concentration of $\mathrm{Zn}$ in the samples varied from $22.4 \mathrm{mg} / \mathrm{l}$ in Al-Hamza city of residential nature (S19) to $49.45 \mathrm{mg} / \mathrm{l}$ in Al-Thaqlin district (S2) of industrial nature near the factory of plastic and fabric. The average value of $\mathrm{Zn}$ concentration in the soil samples is $29.82 \pm 3.54$; this value is about twofold lower than the acceptable limit of $\mathrm{Zn}$ in soil samples $57.5 \mathrm{mg} / \mathrm{l}$ [22]. These findings indicate that the soil samples of the present study are not polluted by $\mathrm{Cu}$ and $\mathrm{Zn}$ metals.

According to Table 2, the mean value of $\mathrm{Pb}$ levels in soil samples of the study area is $31.75 \pm 2.65 \mathrm{mg} / \mathrm{l}$ this value is higher than the levels of $\mathrm{Cd}, \mathrm{Cu}$ and $\mathrm{Zn}$; so that the levels of toxic elements in soil samples of the present study can be arranged in the following sequence (from
Table 2 Heavy metals concentrations in soil samples of Al-Diwaniyah governorate

\begin{tabular}{|c|c|c|c|c|c|}
\hline \multirow[t]{2}{*}{ No } & \multirow[t]{2}{*}{ Sample code } & \multicolumn{4}{|c|}{ Heavy metals concentrations (mg/l) } \\
\hline & & $\mathrm{Pb}$ & $\mathrm{Cd}$ & $\mathrm{Cu}$ & $\mathrm{Zn}$ \\
\hline 1 & S1 & 32 & 1.98 & 17.65 & 32 \\
\hline 2 & $\mathrm{~S} 2$ & 34 & 2.25 & 19.42 & 49.54 \\
\hline 3 & $\mathrm{~S} 3$ & 29 & 2.16 & 13.3 & 29.2 \\
\hline 4 & S4 & 30 & 2 & 22.14 & 34.46 \\
\hline 5 & S5 & 20 & 1.81 & 17.12 & 22.72 \\
\hline 6 & S6 & 31 & 1.3 & 14.23 & 23.4 \\
\hline 7 & S7 & 33 & 2.72 & 24.12 & 28.8 \\
\hline 8 & S8 & 28 & 0.98 & 17.3 & 23.4 \\
\hline 9 & S9 & 41 & 1.2 & 20 & 31.68 \\
\hline 10 & S10 & 38 & 1.3 & 16 & 33.6 \\
\hline 11 & $\mathrm{~S} 11$ & 31 & 2.27 & 16.78 & 38.8 \\
\hline 12 & S12 & 30 & 2.16 & 18.6 & 25.6 \\
\hline 13 & S13 & 36 & 1.84 & 21.32 & 28.73 \\
\hline 14 & S14 & 40 & 1.22 & 20.1 & 32.4 \\
\hline 15 & S15 & 27 & 1.76 & 16.6 & 25.3 \\
\hline 16 & S16 & 30 & 1.83 & 17 & 24 \\
\hline 17 & S17 & 39 & 1.7 & 18 & 26.77 \\
\hline 18 & S18 & 27 & 1.8 & 23.3 & 29.6 \\
\hline 19 & S19 & 22 & 1.7 & 18.1 & 22.4 \\
\hline 20 & $\mathrm{~S} 20$ & 37 & 2.11 & 19.2 & 34.12 \\
\hline \multicolumn{2}{|c|}{ Mean \pm SD } & $31.75 \pm 2.65$ & $1.804 \pm 0.43$ & $18.51 \pm 2.77$ & $29.82 \pm 3.54$ \\
\hline
\end{tabular}




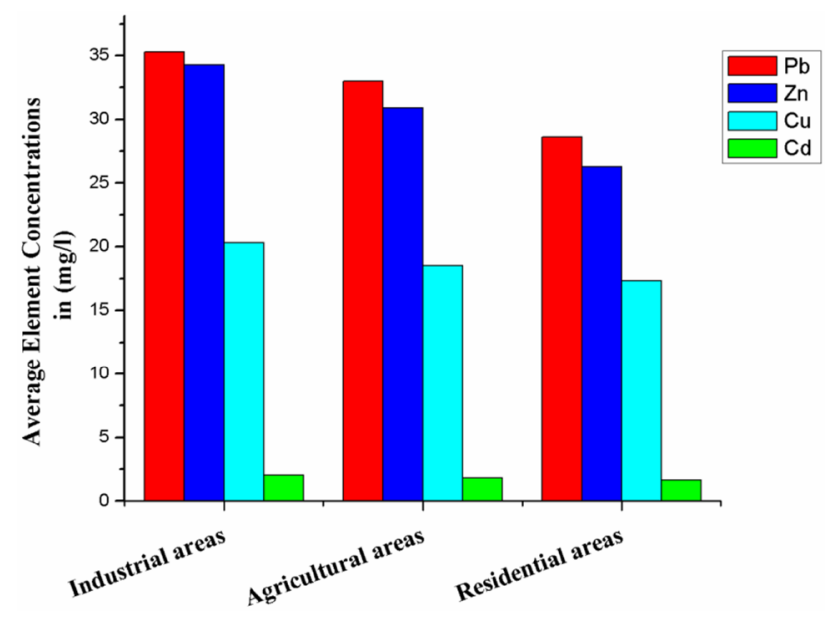

Fig. 1 Average values of elements concentrations in soil samples as a function of the region nature

more available to less available): $\mathrm{Pb}>\mathrm{Zn}>\mathrm{Cu}>\mathrm{Cd}$. The increase in $\mathrm{Pb}$ concentration in the soil samples of industrial areas could be ascribed to petrol combustion and industrial activity in and around the study area. This result is in agreement with those of other researchers $[1,17]$.

Figure 1 illustrates the concentrations of $\mathrm{Pb}, \mathrm{Cd}, \mathrm{Cu}$ and $\mathrm{Zn}$ in soil samples of Al-Diwaniyah governorate as a function of the region nature, where the study areas varied in nature, which included residential, agricultural and industrial areas. From this figure the mean values of $\mathrm{Pb}$, $\mathrm{Cd}, \mathrm{Cu}$ and $\mathrm{Zn}$ concentrations in soil samples collected from industrial areas are $(35.3,2.02,20.31$ and $34.26 \mathrm{mg} / \mathrm{l})$ respectively, These mean values are significantly higher than the concentrations of heavy metals in the agricultural and residential areas. These findings indicated that the industrial areas are more polluted than other areas due to the human activities and industrial applications, the degrees of pollution of the toxic elements in soil samples of the study area are ranked as follows: industrial > agricultural $>$ residential where this finding is in agreement with those of other researchers [1,23-25]. The reason of pollution in industrial areas of Al-Diwaniyah governorate can be attributed to the unchecked wastes of factories, emitted gases form electrical power plants in addition to waste of car repair garages. Whilst the pollution of toxic metals in soil samples of the agricultural areas is attributed to the use of chemical fertilizers and insecticides in agricultural fields. Further the contamination of the residential areas is due to untreated sewage water, motor vehicle exhausts and the use of leaded gasoline.

The concentrations of heavy metals $\mathrm{Pb}, \mathrm{Cd}, \mathrm{Cu}$ and $\mathrm{Zn}$ in soil samples of other locations are different and summarised in Table 3. This table shows that the highest records of the heavy metals values are observed in Isfahan, Iran and Tamilnadu, India [1,26]. The figures of the present study are higher than the levels in Sadat, Egypt and lower than those of Isfahan, Iran; Tamilnadu, India and Birmingham, UK. As the present investigation was the first study ever carried out involving soil samples of different areas of Al-Diwaniyah governorate southern Iraq, the results obtained are now serving as the reference data for future studies.

\section{Conclusion}

The heavy metals concentrations in soil samples collected from different areas residential, industrial and agricultural of Al-Diwaniyah governorate, southern Iraq have been determined by using AAS technique. The metals $\mathrm{Pb}$ and $\mathrm{Cd}$ are most abundant in the soil samples of the study area due to human activities. The results indicated that the industrial areas are more polluted than the agricultural and residential regions due to the industrial activities. The results of heavy metals concentrations in the present study show that the soil samples are not polluted by $\mathrm{Cu}$ and $\mathrm{Zn}$.
Table 3 Comparison of heavy metals concentration of present work with other countries

\begin{tabular}{lllllll}
\hline No & Locations & \multicolumn{3}{l}{ Analysed Metals in (mg/l) } & \multirow{2}{*}{ References } \\
\cline { 3 - 6 } & & $\mathrm{Pb}$ & $\mathrm{Cd}$ & $\mathrm{Cu}$ & $\mathrm{Zn}$ & \\
\hline 1 & Isfahan, Iran & 139.3 & - & 45.1 & 118.7 & {$[1]$} \\
1 & Tamilnadu, India & 50 & 3.5 & - & 90 & {$[26]$} \\
2 & Birmingham, UK & 48 & 1.62 & 64.9 & 53.4 & {$[27]$} \\
3 & Beijing, China & 28.6 & 0.15 & 23.7 & 65.7 & {$[28]$} \\
4 & Ottawa, Canada & 39.05 & 0.37 & 65.84 & 112.5 & {$[29]$} \\
5 & Sadat, Egypt & 5.89 & 1.2 & 14.1 & - & {$[30]$} \\
6 & Al-Diwaniyah, Iraq & 31.75 & 1.804 & 18.51 & 29.82 & Present study \\
\hline
\end{tabular}


Acknowledgements Support from Department of Physics, College of Education, University of Al-Qadisiyah, Al-Diwaniyah, Iraq is gratefully acknowledged. Our sincere thanks to Dr. Feleah H Ali. Head of Chemistry and Physics Research Department, Ministry of Science and Technology, Baghdad, Iraq, for his technical help in AA spectroscopy.

\section{Compliance with ethical standards}

Conflict of interest The authors declare that they have no conflict of interest.

\section{References}

1. Dankoub Z, Ayoubi S, Khademi H, Sheng-Gao LU (2012) Spatial distribution of magnetic properties and selected heavy metals in calcareous soils as affected by land use in the Isfahan region, Central Iran. Pedosphere 22(1):33-47

2. Taghipour M, Ayoubi S, Khademi H (2011) Contribution of lithologic and anthropogenic factors to surface soil heavy metals in western Iran using multivariate geostatistical analyses. Soil Sedim Contam Int J 20(8):921-937

3. Karimi R, Ayoubi S, Jalalian A, Sheikh-Hosseini AR, Afyuni M (2011) Relationships between magnetic susceptibility and heavy metals in urban topsoils in the arid region of Isfahan, central Iran. J Appl Geophys 74(1):1-7

4. Naimi S, Ayoubi S (2013) Vertical and horizontal distribution of magnetic susceptibility and metal contents in an industrial district of central Iran. J Appl Geophys 96:55-66

5. Naderizadeh Z, Khademi H, Ayoubi S (2016) Biomonitoring of atmospheric heavy metals pollution using dust deposited on date palm leaves in southwestern Iran. Atmósfera 29(2):141-155

6. Ayoubi S, Soltani Z, Khademi H (2018) Particle size distribution of heavy metals and magnetic susceptibility in an industrial site. Bull Environ Contam Toxicol 100(5):708-714

7. Ayoubi S, Jabbari M, Khademi H (2018) Multiple linear modeling between soil properties, magnetic susceptibility and heavy metals in various land uses. Model Earth Syst Environ 4(2):579-589

8. Wei $B$, Yang $L$ (2010) A review of heavy metal contaminations in urban soils, urban road dusts and agricultural soils from China. Microchem J 94(2):99-107

9. Lu X, Wang L, Lei K, Huang J, Zhai Y (2009) Contamination assessment of copper, lead, zinc, manganese and nickel in street dust of Baoji, NW China. J Hazard Mater 161(2-3):1058-1062

10. Morton-Bermea $\mathrm{O}$, Hernández-Álvarez $\mathrm{E}$, González-Hernández G, Romero F, Lozano R, Beramendi-Orosco LE (2009) Assessment of heavy metal pollution in urban topsoils from the metropolitan area of Mexico City. J Geochem Explor 101(3):218-224

11. Yang $P$, Mao R, Shao H, Gao Y (2009) The spatial variability of heavy metal distribution in the suburban farmland of Taihang Piedmont Plain, China. Comptes Rendus Biol 332(6):558-566

12. Strumylaite $L$, Bogusevicius $A$, Abdrakhmanov $O$, Baranauskiene D, Kregzdyte R, Pranys D, Poskiene L (2009) Association of cadmium with human breast cancer. Epidemiology 20(6):S178

13. Waisberg M, Joseph P, Hale B, Beyersmann D (2003) Molecular and cellular mechanisms of cadmium carcinogenesis. Toxicology 192(2-3):95-117

14. Aswood MS, Al-Hamzawi AA, Khadayeir AA (2019) Natural radionuclides in six selected fish consumed in south Iraq and their committed effective doses. SN Appl Sci 1(1):21

15. Al-Hamzawi AA, Jaafar MS, Tawfiq NF (2015) Concentration of uranium in human cancerous tissues of Southern Iraqi patients using fission track analysis. J Radioanal Nucl Chem 303(3):1703-1709

16. Al-Hamzawi AA, Jaafar MS, Tawfiq NF (2014) Uranium concentration in blood samples of Southern Iraqi leukemia patients using CR-39 track detector. J Radioanal Nucl Chem 299(3):1267-1272

17. Al-Hamzawi AA, Jaafar MS, Kabir NA, Tawfiq NF (2015) Concentrations of $\mathrm{Pb}, \mathrm{Ni}$ and $\mathrm{Cd}$ in urine and tissue samples of southern Iraqi cancer patients. J Appl Sci Agric 10(5):126-133

18. Al-Hamzawi AA (2017) Natural radioactivity measurements in vegetables at Al-Diwaniyah Governorate, Iraq and evaluation of radiological hazard. Al-Nahrain J Sci 20(4):51-55

19. Madrid L, Díaz-Barrientos E, Madrid F (2002) Distribution of heavy metal contents of urban soils in parks of Seville. Chemosphere 49(10):1301-1308

20. Sezgi N, Ozcan HK, Demir G, Nemlioglu S, Bayat C (2004) Determination of heavy metal concentrations in street dusts in Istanbul E-5 highway. Environ Int 29(7):979-985

21. Ahmed F, Ishiga $H$ (2006) Trace metal concentrations in street dusts of Dhaka city, Bangladesh. Atmos Environ 40(21):3835-3844

22. Du Y, Gao B, Zhou H, Ju X, Hao H, Yin S (2013) Health risk assessment of heavy metals in road dusts in urban parks of Beijing, China. Proc Environ Sci 18:299-309

23. Babula P, Adam V, Opatrilova R, Zehnalek J, Havel L, Kizek R (2008) Uncommon heavy metals, metalloids and their plant toxicity: a review. Environ Chem Lett 6:189-213

24. Poggio L, Vrščaj B, Hepperle E, Schulin R, Marsan FA (2008) Introducing a method of human health risk evaluation for planning and soil quality management of heavy metal-polluted soils-an example from Grugliasco (Italy). Landsc Urban Plan 88(2-4):64-72

25. Zhang XY, Lin FF, Wong MT, Feng XL, Wang K (2009) Identification of soil heavy metal sources from anthropogenic activities and pollution assessment of Fuyang County, China. Environ Monit Assess 154(1-4):439

26. Devanesan E, Gandhi MS, Selvapandiyan M, Senthilkumar G, Ravisankar R (2017) Heavy metal and potential ecological risk assessment in sediments collected from Poombuhar to Karaikal Coast of Tamilnadu using Energy dispersive X-ray fluorescence (EDXRF) technique. Beni-Suef Univ J Basic Appl Sci 6(3):285-292

27. Charlesworth S, Everett M, McCarthy R, Ordonez A, De Miguel $E$ (2003) A comparative study of heavy metal concentration and distribution in deposited street dusts in a large and a small urban area: Birmingham and Coventry, West Midlands, UK. Environ Int 29(5):563-573

28. Zheng YM, Chen TB, He JZ (2008) Multivariate geostatistical analysis of heavy metals in topsoils from Beijing, China. J Soils Sediments 8(1):51-58

29. Rasmussen PE, Subramanian KS, Jessiman BJ (2001) A multi-element profile of house dust in relation to exterior dust and soils in the city of Ottawa, Canada. Sci Total Environ 267(1-3):125-140

30. Nassef M, El-Tahawy M S, Hannigan R, EL Sayed KA (2006) Determination of some heavy metals in the environment of Sadat industrial city. In: Proceeding of the 2 nd environmental physics conference, Alexandria, Egypt

Publisher's Note Springer Nature remains neutral with regard to jurisdictional claims in published maps and institutional affiliations. 